Rev. Int. Contam. Ambie. 33 (Especial Biotecnología e ingeniería ambiental) 105-114, 2017

DOI: 10.20937/RICA.2017.33.esp01.09

\title{
BIOREMEDIATION OF SOILS FROM OIL SPILL IMPACTED SITES USING BIOAUGMENTATION WITH BIOSURFACTANTS PRODUCING, NATIVE, FREE-LIVING NITROGEN FIXING BACTERIA
}

\author{
Josefina PÉREZ VARGAS ${ }^{1 *}$, Sergio Esteban VIGUERAS CARMONA ${ }^{1}$, Enid ZAMUDIO MORENO², \\ Noemí Araceli RIVERA CASADO ${ }^{2}$ and Graciano CALVA CALVA ${ }^{2}$
}

${ }^{1}$ Laboratorio Biotecnología Ambiental, División de Ingeniería Bioquímica, Tecnológico de Estudios Superiores de Ecatepec. Avenida Tecnológico sin número, Colonia Valle de Anáhuac, Ecatepec de Morelos, Estado de México, México, C. P. 55210

${ }^{2}$ Departamento de Biotecnología y Bioingeniería, Centro de Investigación y de Estudios Avanzados del Instituto Politécnico Nacional. Avenida Instituto Politécnico Nacional 2508, Colonia San Pedro Zacatenco, Ciudad de México, México, C. P. 07360

*Corresponding author: djperezvargas@hotmail.com

(Received November 2015; accepted October 2016)

Key words: rhamnolipid, emulsification index, biopile, aged sites, NFB

\begin{abstract}
Oil spills are the most common source of environmental damage in areas with oil extraction activities. Bioaugmentation is a bioremediation technology that involves increasing microbiotas that can remove contaminant compounds from soils or water. This can be achieved by supplying exogenous microorganisms or by increasing the abundance of native microorganisms able to remove the contaminants. As biosurfactants enhance the solubility and bioavailability of hydrophobic compounds, the addition of native bacteria that produce biosurfactants may improve the rates of hydrocarbons biodegradation at oil spill impacted sites. The objective of this study was to investigate the effectiveness of using the bioaugmentation of native, free-living nitrogen fixing bacteria (NFB) that are able to remove hydrocarbons and produce biosurfactant compounds, to bioremediate soils at long term oil spill impacted sites containing total hydrocarbon (TH) levels of $120000 \mathrm{ppm}$. For this study, two NFB that produce biosurfactants were selected from a group of 24 previously isolated from a long-term oil spill impacted site. After 16 months of bioaugmentation, the hydrocarbons removal reached $80 \%$. The NFB count increased from $13 \times 10^{4}$ colony-forming units (CFU) to $2 \times 10^{9} \mathrm{CFU}$, and the total bacterial population increased from $5 \times 10^{4} \mathrm{CFU}$ to $22 \times 10^{11}$ CFU. According to literature, this is the first bioaugmentation study using native NFB biosurfactant producers to bioremediate soils from aged oil spill impacted sites. As such, these results demonstrate the potential of this bioaugmentation strategy for the bioremediation of oil spill impacted sites, especially those low in nitrogen.
\end{abstract}

Palabras clave: ramnolípido, índice de emulsificación, biopila, intemperizado, NFB 


\section{RESUMEN}

Los derrames de petróleo son la fuente más común de daños al ambiente en zonas con actividades de extracción de petróleo. La bioaumentación es una tecnología de biorremediación que implica un incremento en la microbiota capaz de eliminar compuestos contaminantes del suelo y agua. Esto se puede lograr mediante la adición de microorganismos exógenos o aumentando la abundancia de microorganismos nativos capaces de remover los contaminantes. Dado que los biosurfactantes mejoran la solubilidad y la biodisponibilidad de compuestos hidrofóbicos, la adición de bacterias nativas productoras de biosurfactantes puede mejorar las tasas de biodegradación de hidrocarburos en suelos de sitios impactados por derrames de petróleo. El objetivo de este trabajo fue investigar la efectividad de la bioaumentación de bacterias nativas, de vida libre, fijadoras de nitrógeno (NFB, por sus siglas en inglés), capaces de eliminar hidrocarburos y producir biosurfactantes, sobre la biorremediación de suelos procedentes de sitios intemperizados después de haber sido impactados por derrames de petróleo y con un contenido de hidrocarburos (TH, por sus siglas en inglés) de 120000 ppm. Para este estudio, dos NFB productoras de biosurfactantes fueron seleccionadas de un grupo de 24 previamente aisladas de sitios impactados por derrames de petróleo. Después de 16 meses de bioaumentación, la remoción de hidrocarburos alcanzó un 80 $\%$. La cuenta de NFB aumentó de $13 \times 10^{4}$ unidades formadoras de colonias (UFC) a $2 \times 10^{9}$ UFC y la población bacteriana total aumentó de $5 \times 10^{4}$ UFC a $22 \times 10^{11}$ UFC. Según la literatura, éste es el primer reporte sobre bioaumentación usando NFB nativas, productoras de biosurfactantes, aplicada a la biorremediación de suelos de sitios intemperizados afectados por derrames de petróleo. Por consiguiente, los resultados demuestran el potencial de esta estrategia de bioaumentación para la biorremediación de sitios afectados por derrames de petróleo, especialmente aquellos pobres en nitrógeno.

\section{INTRODUCTION}

The exploration, transportation and processing of crude oil may result in accidents, spills, and leakage of oil hydrocarbons. As such, human health and the environment may be impacted in oil-producing countries and regions (Akpor et al. 2007, Tang et al. 2012). The chemical, physical and biological properties of soils can be drastically altered by oil spills, leaks, drilling waste and oily water (John et al. 2011). For example, the petroleum industry in Tabasco, Mexico is responsible for an average of 114 environmental incidents a year due to oil spills and leaks (Rivera-Casado et al. 2015, Palma-Cruz et al. 2016). Soils polluted by hydrocarbons affect not only human health but also living organisms at the impacted sites, including plants (Merkl et al. 2005, Rivera-Casado et al. 2015) and microorganisms (Akpor et al. 2007, Peng et al. 2009).

It has been reported that the harmful effects of oil contamination are amplified over time because of the aging phenomenon. As time passes, hydrocarbon compounds are sequestered, lowering their accessibility, bioavailability, biological toxicity and biodegradability (Semple et al. 2004, Ruffini et al. 2016). Consequently, some bioremediation strategies used to remediate oil hydrocarbon contaminated soils have failed because of their reduced bioavailability and other aging effects present, that have resulted in reduced biodegradation efficiency (Tang et al. 2012). Bioaugmentation is an alternative bioremediation strategy that can be used for the treatment of aged oil impacted sites by increasing the microbiota present by either supplying exogenous microorganisms (Escalante-Espinosa et al. 2005, Mancera-López et al. 2008) or increasing the abundance of the native microorganisms that can remove the contaminants (Bento et al. 2005, Alisi et al. 2009, Ruffini et al. 2016). Although some studies indicate that exogenous microorganisms often do not survive in the impacted environments (Gentry et al. 2004), and thus do not improve the bioremediation process, several studies claim that bioaugmentation with native microorganisms can increase the persistence and activity of introduced microorganisms (Gentry et al. 2004, Tyagi et al. 2011). Bioaugmentation with native microorganisms is advantageous to other bioremediation techniques (Alisi et al. 2009, Ruffini et al. 2016), in that the microbial removal process of the contaminants can start as soon as the native microorganisms are 
introduced into the bioremediation system without further nutritive or physical and chemical changes required. In this respect, it has been reported that bioremediation efficacy may depend more on the selectivity and specialization of the added microorganisms than on the nutrients available in the environment (Hamdi et al. 2007). Therefore, the increased contaminant removal rates observed using native microorganisms may be, because this reintroduced microbiota is already adapted to the impacted site (Bento et al. 2005).

Biosurfactants enhance the solubility and bioavailability of hydrophobic compounds by emulsification (Medina-Moreno et al. 2013) and by reverting some of the aging effects (Bordoloi and Konwar 2009, Tyagi et al. 2011). As such, the introduction of biosurfactant producers should improve the biodegradation rates of oil hydrocarbons by increasing their bioaccessibility and bioavailability to the organisms at the impacted sites. The objective of this study was to investigate the bioremediation effectiveness of bioaugmentation ex-situ in biopile systems using two, native, and biosurfactant producing nitrogen fixing bacteria (NFB). The NFB were previously isolated from an aged oil spill impacted site containing 120 $000 \mathrm{ppm}$ of total hydrocarbons $(\mathrm{TH})$ as reported by Pérez et al. (2000, 2006).

\section{MATERIALS AND METHODS}

\section{Soil characterization and site descriptions}

This study involved the collection of soil $(0-35 \mathrm{~cm}$ depth) from an aged oil spill contaminated site at Sanchez Magallanes Field, oil well 205, as described by Palma-Cruz et al. $(2004,2016)$. The soil was airdried, mixed, and sieved through a number 10 mesh ( $2 \mathrm{~mm}$ sieve) and then classified according to its sand-silt-clay composition (Ashworth et al. 2001). The soil characterization was performed as reported by Palma-Cruz et al. (2004, 2016). The collected soil contained $120000 \mathrm{ppm}$ of total hydrocarbons $(\mathrm{TH})$, 0.11-0.08\% total nitrogen $(\mathrm{N})$, and 2.41-1.96\% organic carbon (C). The soil was obtained at $18^{\circ}$ $08^{\prime} 29.1^{\prime \prime} \mathrm{N}$ latitude, and $93^{\circ} 53^{\prime} 31.5^{\prime}$ "W longitude, in the physiographic subprovince plateau and marsh of Tabasco, Mexico in the Coastal Plateau of the South Gulf of Mexico, with a maximum altitude of 20 masl. The site was first impacted by an oil spill in 1950, and has since suffered from periodic oil spills and further contamination from recurring flooding, which occurs at the site during the 6-month rainy season (Palma-Cruz et al. 2004, 2016).

\section{Cultures of NFB biosurfactant producers to inoculate biopiles}

Two NFB biosurfactant producers from a group of 24 previously isolated from long term oil spill impacted sites as reported (Pérez et al. 2000, 2006), were used for this study. Briefly, $1 \mathrm{~g}$ of air dried soil was diluted in saline solution (0.9\%). Dilutions were plated on nutritive culture medium (Merck) and the developed bacterial colonies were transferred to plates containing solid Rennie culture medium (Rennie 1987) with kerosene (5 g/L) as the sole carbon source to screen the NFBs ability to grow in hydrocarbons. Two of these NFB were selected for this study on the basis of their kerosene hydrocarbon removal capabilities (Pérez et al. 2000, 2010) and their biosurfactant production capacity when cultivated under nitrogen fixation conditions. (Pérez et al. 2011). Biomass samples from these cultures were individually transferred into $250 \mathrm{~mL}$ conical flasks containing $100 \mathrm{~mL}$ of Rennie liquid medium supplemented with kerosene $(10 \mathrm{~g} / \mathrm{L})$ as the sole source of carbon. The flask cultures were incubated at $28{ }^{\circ} \mathrm{C}$ for 5 days at $100 \mathrm{rpm}$. The NFB biosurfactant producers were transferred to $2 \mathrm{~L}$ flasks containing $1 \mathrm{~L}$ of fresh Rennie culture medium and cultivated under the same conditions. The contents of both bacterial cultures were combined and used to inoculate each biopile system.

\section{Biosurfactant production assay}

The biosurfactant production assay was performed as previously reported (Pérez et al. 2010). Briefly, the biosurfactant that accumulated in the culture medium was isolated $3 \times$ with ethyl acetate $(1: 1 \mathrm{v} / \mathrm{v})$. The organic extracts from $1 \mathrm{~L}$ of the bacterial culture were pulled, evaporated, and resuspended in $5 \mathrm{~mL}$ of sodium bicarbonate. The biosurfactant was recovered from the bicarbonate solution by thin layer chromatography (TLC) using a mixture of chloroform, methanol and acetic acid (60:20:4). The silica fraction from the TLC plates carrying the putative biosurfactant compound was resuspended in ethyl acetate and centrifuged $(5000 \mathrm{rpm})$ the supernatant was evaporated. The solid biosurfactant was redissolved in water $(200 \mathrm{mg} / \mathrm{L})$ for the emulsification index assay.

\section{Emulsification index assay (IE 24)}

The emulsification index assay was used to evaluate the emulsification efficiency of the biosurfactant extracted from the NFB cultures compared to several hydrophobic compounds according to the method described by Cooper and Goldenberg (1987). Briefly, 
$4 \mathrm{~g}$ of a hydrophobic compound was added to $6 \mathrm{~mL}$ of the aqueous surfactant solution. The mix was vortexed at a high speed for 2 min and then kept at room temperature for $24 \mathrm{~h}$. The emulsification index (IE 24) was estimated as a percentage of the height of the emulsion layer regarding to the overall mixture. The hydrophobic compounds included in this study were paraffin, kerosene, diesel, motor oil, and soybean oil.

\section{Biopile treatments}

Contaminated soil (100 kg) from the impacted-site was ground and sieved through $2 \mathrm{~mm}$ mesh. Samples weighing $12 \mathrm{~kg}$ were used to prepare biopiles with non-treated soil $\left(\mathrm{B}_{0}\right)$ which was used as a control to evaluate hydrocarbon evaporation and natural microbial hydrocarbon removal. Study samples included soil inoculated with $1 \mathrm{~L}$ culture of each NFB strains $\left(\mathrm{B}_{1}\right)$, soil plus $10 \%(\mathrm{w} / \mathrm{w}) 4 \times$ autoclaved sugar cane bagasse $\left(\mathrm{B}_{2}\right)$, soil inoculated with $1 \mathrm{~L}$ culture of each NFB strains plus $10 \%(w / w) 4 \times$ autoclaved sugar cane bagasse $\left(B_{3}\right)$. The biosurfactant produced by both NFB strains was typically extracellular (Pérez et al. 2010), as such, complete bacterial cultures were added to the biopile treatments with NFB. The biopiles were incubated in a culture room at $29 \pm 2{ }^{\circ} \mathrm{C}$ with $30 \%$ humidity and maintained by adding demineralized water when necessary.

\section{Changes in the microbial populations present in the biopiles}

Changes in total microbial counts (TMC), nitrogen fixing bacteria (NFB) counts, and fungus counts (FC) in the biopiles were estimated by inoculating serial dilutions of microbial suspensions from samples of $1 \mathrm{~g}$ of air dried soil onto plates with nutritive, Rennie, or PDA culture medium as previously described. The number of colony-forming units (CFU) was calculated and considered representative of the number of cells present in $1 \mathrm{~g}$ of soil from a biopile. The results were reported as a unit of soil sample from four plates. Typically, the standard error for the CFU was between $5-20 \%$ of the sample mean.

\section{Total hydrocarbons (TH) isolation and gas chro- matography (GC) analysis}

Hydrocarbons were soxhlet-extracted from $1 \mathrm{~g}$ of dried soil with $100 \mathrm{~mL}$ of dichloromethane (35 cycles for an extraction efficiency of $85 \%$ ). The solvent was evaporated and the residue redissolved in $25 \mathrm{~mL}$ of hexane to be analyzed by gas chromatography to measure the total hydrocarbon content. Chromatographic analysis was performed with a Varian chromatograph, model 3800 , equipped with a flame ionization detector and a wall coated open tubular (WCOT) capillary column of fused silica with CP-Sil-8CB phase $(25 \mathrm{~m} \times 0.35 \mathrm{~mm}$ of internal diameter(ID)). The temperatures for the injector, the column, and the detector were $220^{\circ} \mathrm{C}, 100{ }^{\circ} \mathrm{C}$ for 2 min with subsequent increases of $10^{\circ} \mathrm{C}$ per minute until $270{ }^{\circ} \mathrm{C}$ and $200{ }^{\circ} \mathrm{C}$ were reached, respectively. Hydrocarbon removal was estimated from at least three independent samples by subtracting the area of the control treatment chromatograms from that of the sample treatment chromatograms.

\section{Assays to measure the physical and chemical properties of soil in the biopiles}

To assay humidity, $\mathrm{pH}$, conductivity, texture, microbial total count, fungi and NFB in the biopiles, dried soil samples were measured using standard methods (Rennie 1987, Jorgensen et al. 2000, Fernández-Linarez et al. 2006).

\section{Statistical analyses}

The SPSS V 15 statistical package (SPSS Inc, 2006) and microsoft excel 2002 software were used. The TH effect over TH removal was evaluated by the analysis of variance (ANOVA) of residual hydrocarbons. The Duncan's test at 0.10 probability level was used for post hoc analysis to evaluate significant differences between treatments. All data represent the average of at least three independent samples.

\section{RESULTS}

\section{Soil characterization and isolation of NFB biosur- factant producers}

The contaminated soil from which the NFB biosurfactant producer strains were isolated contained $120000 \mathrm{ppm}$ of TH. The soil was extensively flooded, Gleysol type (Table I), and had very low plant biodiversity, which is typical of the marshland and grassland communities in this area (Palma et al. $2004,2016)$. Based on the soils content of clay (41.7 \pm $3.9)$, silt (17.8 \pm 6.1 ), and sand (40.4 \pm 7.6 ), its texture can be defined as clay, although very close to sandyclay, exhibiting slow internal drainage and electrical conductivity of $2 \mathrm{mS} / \mathrm{cm}$. The initial physical and chemical characterization of soil samples revealed a high density $\left(1.29 \mathrm{~g} / \mathrm{cm}^{3}\right)$, probably due to the high clay content and high cationic exchange capacity (42.1 $\mathrm{meq} / \mathrm{kg}$ ). The low nitrogen, phosphorous, and organic material content may have resulted from the harmful effects of oil contamination and the aging phenomenon on the flora and fauna at the study site. From this 
TABLE I. PHYSICOCHEMICAL CHARACTERISTICS OF THE SOIL

\begin{tabular}{lcc}
\hline \multicolumn{1}{l}{ Type } & Gleysol \\
\hline & $\quad$ clay $(\%)$ & $41.7 \pm 3.9$ \\
Texture & silt $(\%)$ & $17.8 \pm 6.1$ \\
& sand $(\%)$ & $40.4 \pm 7.6$ \\
Textural class & clay - candy clay* \\
Organic material (\%) & $2.41 \pm 0.39$ \\
Total nitrogen $(\%)$ & $0.1108 \pm 0.02$ \\
Phosphorus $(\mathrm{mg} / \mathrm{kg})$ & $36.53 \pm 1.86$ \\
pH & 7.4 \\
CEC (meq/kg) & $42.1 \pm 3.49$ \\
Apparent density $\left(\mathrm{g} / \mathrm{cm}^{3}\right)$ & $1.29 \pm 0.05$ \\
\hline
\end{tabular}

*After the soil texture triangle classification. $\mathrm{CEC}=$ cationexchange capacity.

soil, 24 NFB strains able to grow in Rennie culture medium with kerosene as the only source of carbon were isolated. However, only two strains produced slimy biosurfactants with strong emulsification abilities (Fig. 1). Both biosurfactant producing NFB strains were named orange or salmon culture (SC) and white or transparent bleached culture (BC), respectively. They were also Gram negative coccobacillus bacteria.

After thin layer chromatography analysis of crude and purified extracts (Fig. 1A), it was found that the biosurfactant from both bacterial strains might be composed of rhamnolipid mixtures (Fig. 1B), similar to those reported for Pseudomonas and expressed in Escherichia coli by Mondello (1989). The capacity of the TLC purified biosurfactant to emulsify several hydrophobic compounds, such as paraffin, kerosene, motor oil, and soybean oil is shown in figure 1C.
These biosurfactants showed low emulsifying abilities for long chain alkanes (e.g., paraffin), but high emulsification abilities for mixtures containing polar residues (e.g., motor oil and kerosene, which the first can contain esters compounds, and the second nitrogen and sulfur compounds). The biosurfactant's emulsifying index was $50 \%$ for non-sterile kerosene and diesel, and $70 \%$ for engine oil. However, glycerol-fatty acids contained in soybean oil were not emulsified (Fig. 1C). Typically, both bacterial strains showed biosurfactant production of approximately $3 \mathrm{~g} / \mathrm{L}$ of cell-free culture medium when grown under nitrogen fixation conditions using kerosene as the sole source of carbon.

\section{Bioremediation by bioaugmentation with native NFB populations}

Cultures of the isolated NFB biosurfactant producing strains were used to study the effects of bioremediation using bioaugmentation at the oil spill impacted soils with total hydrocarbon levels of $120000 \mathrm{ppm}$. Before the addition of the NFB, the soil was sticky and heavy due to its high hydrocarbon content (Fig. 2A). After 16 months of treatment in the biopiles the soil consistency changed drastically to less sticky and oily (Fig. 2B). Although the texture and the physical and chemical characteristics of the soil, such as cationic exchange capacity, $\mathrm{pH}$ and conductivity remained virtually unchanged: clay, $\mathrm{pH} 7$, and conductivity of $2 \mathrm{mS} / \mathrm{cm}$.

To investigate whether the isolated NFB that were reintroduced to the contaminated soil affected the microbial population in the biopiles, changes in TMC,
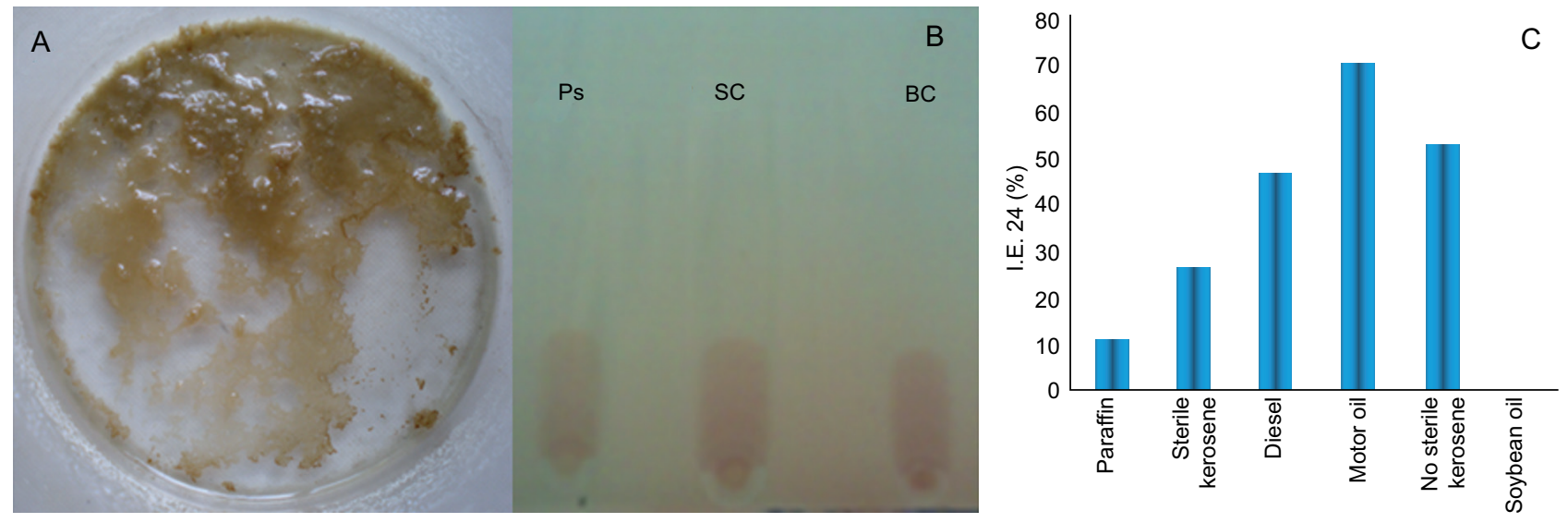

Fig. 1. The appearance (A), and thin layer chromatography plate of the biosurfactant crude extracts from the nitrogen fixing bacteria salmon (SC) and bleached (BC) strains cultures (B) relative to a rhamnolipid from Pseudomonas aeruginosa (Ps). The emulsification index after $24 \mathrm{~h}$ (IE 24) for the purified biosurfactant against several hydrophobic compounds (C). Kerosene was sterilized by filtration across a $0.25 \mu$ polyethersulfone membrane 

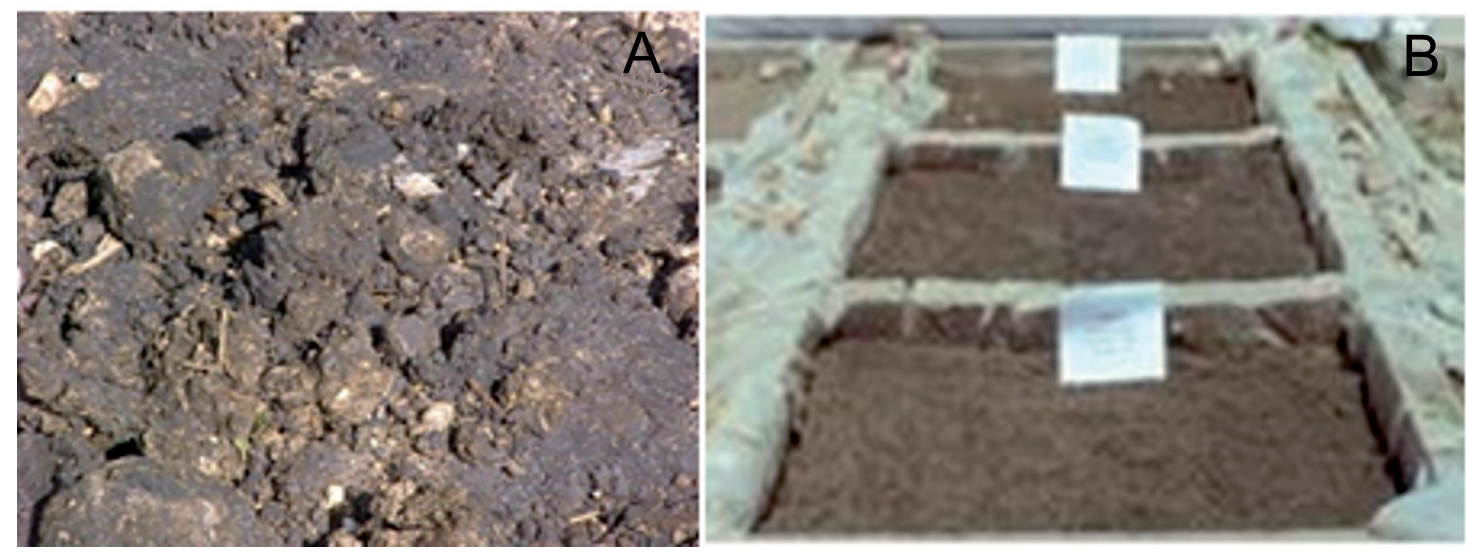

Fig. 2. Soil appearance before (A), and after 16 months of the native nitrogen fixing bacteria bioaugmentation, incubated in a culture room at $29 \pm 2{ }^{\circ} \mathrm{C}$ and $30 \%$ humidity

TABLE II. CHANGES IN COLONY FORMING UNITS (CFU), IN TOTAL MICROBIAL COUNT (TMC), NITROGEN FIXING BACTERIA (NFB) COUNT, AND FUNGUS COUNT (FC) IN SOILS FROM THE BIOPILES DURING 16 MONTHS OF TREATMENT WITH NFB, CANE BAGASSE, AND NFB + CANE BAGASSE

\begin{tabular}{|c|c|c|c|c|c|c|c|c|c|c|}
\hline \multirow{2}{*}{ Biopile } & \multirow{2}{*}{ Treatment } & \multirow{2}{*}{$\begin{array}{l}\text { Microbial } \\
\text { count type }\end{array}$} & \multicolumn{8}{|c|}{ Time (months) } \\
\hline & & & 0 & 1 & 3 & 6 & 9 & 12 & 15 & 16 \\
\hline \multirow[t]{3}{*}{$\mathrm{B}_{0}$} & \multirow[t]{3}{*}{ Raw Soil } & TMC & $5 * 10^{4}$ & $5 * 10^{4}$ & $6 * 10^{4}$ & $4 * 10^{4}$ & $5 * 10^{4}$ & $5 * 10^{4}$ & $5 * 10^{4}$ & $5 * 10^{4}$ \\
\hline & & NFB & 70 & 70 & 80 & 70 & 80 & 70 & 75 & 72 \\
\hline & & $\mathrm{FC}$ & $3 * 10^{2}$ & $4 * 10^{2}$ & $4 * 10^{2}$ & $6 * 10^{2}$ & $4 * 10^{2}$ & $4 * 10^{2}$ & $6^{*} 10^{2}$ & $5 * 10^{2}$ \\
\hline \multirow{3}{*}{$\mathrm{B}_{1}$} & \multirow[t]{3}{*}{ NFB } & TMC & $5 * 10^{4}$ & $22 * 10^{4}$ & $22 * 10^{5}$ & $22 * 10^{7}$ & $15 * 10^{9}$ & $19 * 10^{10}$ & $18^{*} 10^{11}$ & $22 * 10^{11}$ \\
\hline & & NFB & $13 * 10^{4}$ & $12 * 10^{4}$ & $15 * 10^{3}$ & $22 * 10^{4}$ & $15 * 10^{6}$ & $18 * 10^{6}$ & $20 * 10^{7}$ & $2 * 10^{9}$ \\
\hline & & $\mathrm{FC}$ & $3 * 10^{2}$ & $4 * 10^{2}$ & $4 * 10^{2}$ & $5 * 10^{7}$ & $7 * 10^{8}$ & $1 * 10^{10}$ & $6^{*} 10^{10}$ & $5^{*} 10^{10}$ \\
\hline \multirow[t]{3}{*}{$\mathrm{B}_{2}$} & \multirow[t]{3}{*}{ Cane bagasse } & TMC & $5 * 10^{4}$ & $5 * 10^{4}$ & $6 * 10^{4}$ & $4 * 10^{4}$ & $15 * 10^{5}$ & $19 * 10^{6}$ & $18^{*} 10^{7}$ & $22 * 10^{7}$ \\
\hline & & NFB & 70 & 70 & 80 & 70 & 75 & 86 & 73 & 75 \\
\hline & & $\mathrm{FC}$ & $3 * 10^{2}$ & $4 * 10^{2}$ & $4 * 10^{2}$ & $6 * 10^{2}$ & $15 * 10^{3}$ & $18 * 10^{3}$ & $2 * 10^{5}$ & $18 * 10^{4}$ \\
\hline \multirow[t]{3}{*}{$\mathrm{B}_{3}$} & \multirow{3}{*}{$\begin{array}{l}\mathrm{NFB}+ \\
\text { Cane bagasse }\end{array}$} & TMC & $5 * 10^{4}$ & $5 * 10^{4}$ & $6^{*} 10^{4}$ & $4 * 10^{4}$ & $15^{*} 10^{5}$ & $19 * 10^{6}$ & $18^{*} 10^{7}$ & $22 * 10^{7}$ \\
\hline & & NFB & $1 * 10^{5}$ & $1 * 10^{5}$ & $8 * 10^{4}$ & $7 * 10^{4}$ & $7 * 10^{4}$ & $8 * 10^{4}$ & $7 * 10^{4}$ & $7 * 10^{4}$ \\
\hline & & $\mathrm{FC}$ & $3 * 10^{2}$ & $4 * 10^{2}$ & $4 * 10^{2}$ & $6 * 10^{2}$ & $15^{*} 10^{4}$ & $18 * 10^{4}$ & $2 * 10^{6}$ & $18 * 10^{5}$ \\
\hline
\end{tabular}

Biopiles with raw soil and soil added with cultures of two strains of NFB ( $0.25 \mathrm{~L}$ each $/ \mathrm{kg}$ soil $), 100 \mathrm{~g} / \mathrm{kg}$ soil sterile sugar cane bagasse, or NFB $(0.25 \mathrm{~L}$ each $/ \mathrm{kg}$ soil $)+100 \mathrm{~g} / \mathrm{kg}$ soil sugar cane bagasse were incubated at $30{ }^{\circ} \mathrm{C}$, and $30 \%$ humidity. Sugar cane bagasse was autoclaved $4 \times$. Data represent the mean CFU from four plates. Typically, the standard error for the CFU was between $5-20 \%$ of the sample mean.

NFB counts, and FC were monitored through-out the 16 months of treatment (Table II). During the first 3 months, microbial counts were almost constant for all treatments and microbial types, although this was less noticeable for the NFB and FC. In biopile $\mathrm{B}_{0}$ which had non-treated soil, the microbial count remained practically unchanged over time. However, in treatments $B_{2}$ and $B_{3}$ with added sugar cane bagasse, the TMC and the FC slightly increased. Interestingly, the NFB population remained practically unchanged, suggesting that sugar bagasse cane addition did not favor NFB proliferation. In contrast, bioaugmentation with NFB alone $\left(B_{1}\right)$, resulted in the proliferation of the whole microbial population. After 6 months of treatment every microbial count increased: the NFB count changed from $13 \times 10^{4} \mathrm{CFU}$ just after inoculation to $2 \times 10^{9} \mathrm{CFU}$ after 16 months. Thus, reintroducing native NFB biosurfactant producing strains from the impacted site was critical for the success of the bioaugmentation process and in increasing other microbial population.

The treatment bioaugmented with NFB also showed the best hydrocarbon removal (Fig. 3). After 16 months, the total hydrocarbon content in biopile 


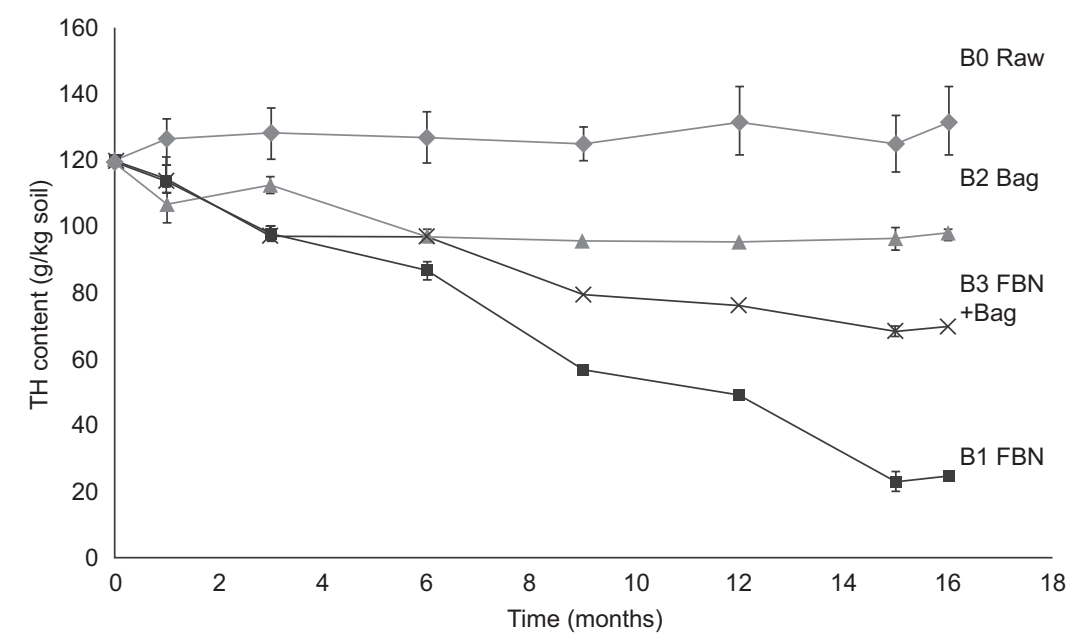

Fig. 3. Time course of total total hydrocarbons $(\mathrm{TH})$ removal in biopiles containing soil from an oil spill impacted site containing $120000 \mathrm{ppm}$ total hydrocarbons. Biopiles were prepared with non-treated contaminated raw soil $\left(\mathrm{B}_{0}\right)$, soil inoculated with a $1 \mathrm{~L}$ culture of each nitrogen fixing bacteria strain $\left(\mathrm{B}_{1}\right)$, soil plus $10 \%(\mathrm{w} / \mathrm{w}) 4 \times$ autoclaved sugar cane bagasse $\left(\mathrm{B}_{2}\right)$, or soil inoculated with a $1 \mathrm{~L}$ culture of each NFB strain plus $10 \%(\mathrm{w} / \mathrm{w}) 4 \times$ autoclaved sugar cane bagasse $\left(B_{3}\right)$. Data represents the mean from four biopiles. Error bars represent the standard deviation from the mean. Typically, the standard error was between $1-1 \%$

$\mathrm{B}_{1}$ decreased from $120 \mathrm{~g} / \mathrm{kg}$ soil to less than $20 \mathrm{~g} / \mathrm{kg}$ soil, suggesting the presence of a higher quantity of hydrocarbonoclastic bacteria than in treatments without bioaugmentation $\left(\mathrm{B}_{0}, \mathrm{~B}_{2}\right)$. However, this was not the case for $\mathrm{B}_{2}$ and $\mathrm{B}_{3}$ treatments, to which sugar cane bagasse, and NFB + sugar cane bagasse, were added respectively. These results suggest that cane bagasse might trap part of the hydrocarbon compounds inhibiting their bioavailability for microbial removal.

Thus, these NFB were able to use hydrocarbons as their only carbon source to produce biosurfactants. In biopiles, they enhanced the hydrocarbon degradation by $80 \%$, lowering the TH content from $120 \mathrm{~g} / \mathrm{kg}$ in the contaminated soil to $24 \mathrm{~g} / \mathrm{kg}$ in the remediated soil.

\section{DISCUSSION}

The results of this work support reports from the literature that suggest that the bioremediation of contaminated soils by bioaugmentation is more effective when native microorganisms from the site are used (Vogel and Walter 2001, Erdoğan et al. 2012). Both NFB strains used in this work were not only native to the impacted site they were also biosurfactant producers. Although the biosurfactant compounds were not characterized, it is likely that they enhanced oil hydrocarbon solubility and thus increased bioaccessibility to the hydrocarbonoclastic microbial community and consequently hydrocarbons removal. These processes were performed by microorganisms that can survive and degrade pollutants in affected environments (Atlas and Bartha 1972, Erdogan et al. 2012, Tang et al. 2012). Several studies have demonstrated the feasibility and potential of bioremediation applications using bioaugmentation strategies to restore hydrocarbon polluted areas both in ex-situ experiments (RojasAvelizapa et al. 2003, Molina-Barahona et al. 2004, Rivera-Cruz et al. 2004) and in-situ at affected sites (Ellis et al. 2000, Tyagi et al. 2011). However, very few studies have used native NFB (John et al. 2011), and to our knowledge there has not been any instances where biosurfactant producing NFB were used. In this study the NFB counts (Table II) and the hydrocarbon removal efficiency measurements (Fig. 3) showed that bioaugmentation improved hydrocarbon removal. The NFB population's capability to use hydrocarbons and produce biosurfactants enhanced hydrocarbon degradation by $80 \%(24 \mathrm{~g} / \mathrm{kg})$ of the initial content $(120 \mathrm{~g} / \mathrm{kg})$. At this stage, it is uncertain if the remaining $20 \%$ of the initial hydrocarbon content was inaccessible or unavailable for biodegradation by the bacteria. However, it seems that the success of bioaugmentation depends on the use of an appropriate inoculum, which was 
biosurfactant producing NFB in this case. It should be noted that the NFB strains used in this work were isolated from the same contaminated soil used in the experiment and were thus likely to be well adapted to the contaminated soil. The results from this work agree with reports that bioaugmentation with native microorganisms from the site to be remediated may improve the ecological recovery process (Jorgensen et al. 2000, Vogel and Walker 2001, John et al. 2011). Jorgensen et al. (2000) divide bioaugmentation approaches into three broad types based on the origin of the microorganisms: 1) where native microorganisms from the target site are cultured and returned to the affected site, 2) where foreign microorganisms are added to the target site, and 3 ) where transgenic microorganisms are used. The process used in this study belongs to the first type, as NFB biosurfactant producers isolated from the impacted sites were used for the bioaugmentation process. The most similar report found in literature is that from by Ruffini et al. (2016). They also used two native biosurfactant producing bacterial strains isolated from heavily polycyclic aromatic hydrocarbon (PAH)-contaminated soil for bioaugmentation in a biopile to increase the bioavailability and degradation of residual PAH contamination in soils from the same site. However, although the bacterial strains were able to use a mixture of PAH as the sole carbon source, they were not NFB. Even though increases in the total microbial counts were evident after some time (3-4 weeks; Table II), the removal process started once the NFB were introduced to the biopile without further nutritive or physical and chemical requirements as it has been reported in other bioaugmentation systems (Alisi et al. 2009). These results support the idea that bioremediation efficacy may depend more on the selectivity and specialization of the microorganisms added than on the nutritive properties of the environment (Hamdi et al. 2007). Additionally, the removal rate may be improved because the reintroduced native microbiotas are already adapted to the impacted site (Bento et al. 2005).

The absence of hydrocarbon removal in the control treatment $\left(\mathrm{B}_{0}\right)$ and the slight removal in biopiles with added cane bagasse (B2) shows that there was no hydrocarbon-evaporation from the biopiles. It also suggests that no hydrocarbonoclastic microorganisms were present or metabolically active in the native contaminated soil. These findings agree with the results reported by Tang et al. (2012) who found a negative correlation between the age of impacted soil and the biodegradation of polycyclic aromatic hydrocarbons, suggesting a reduction in the bioavailability of organic contaminants to microorganisms over time. Therefore, it appears that the hydrocarbon removal we observed can be attributed to bioaugmentation of NFB in the biopile systems. Finally, the hydrocarbon removal in biopile $\mathrm{B}_{1}$, which was bioaugmented with NFB populations that were able to grow with kerosene hydrocarbons as their sole carbon source and to produce biosurfactants, agrees with reports that biosurfactant compounds enhance the solubility of oil hydrocarbons and thus their bioaccessibility and bioavailability, improving the biodegradation rates of organisms present at the impacted site (Bordoloi and Konwar 2009, Tyagi et al. 2011).

\section{CONCLUSIONS}

This is the first experiment performed with real soil from an aged oil spill contaminated site using biosurfactant producing NFB that are native to the target contaminated site. When grown under nitrogen fixing conditions with kerosene as the sole source of carbon, these NFB showed three abilities: to fix nitrogen, to remove hydrocarbons and to produce biosurfactants. Surprisingly, with the bioaugmentation strategy deployed, it was possible to reduce the total hydrocarbon content in the biopiles by $80 \%$ after a 16 -month treatment period (Treatment B1). These results provide insight into the physical, chemical, and biological interactions between hydrocarbon removal and the metabolism of NFB. Furthermore, these results provide insight into a possible bioremediation method for oil-impacted sites, specifically, the bioremediation potential of these NFB to treat nitrogen poor soils contaminated with hydrocarbons.

\section{ACKNOWLEDGMENTS}

This work was supported by the Tecnológico Nacional de México (TNM 366.15-PD), and Consejo Nacional de Ciencia y Tecnología (CONACyT México: 211085-5-29307B). Special acknowledgment is given to Comisión Interinstitucional para el Medio Ambiente y el Desarrollo Social (CIMADES) for the technical assistance during the field studies at the oil extraction and production zones in Tabasco, Mexico. Noemí Araceli Rivera Casado, acknowledges a doctoral fellowship (227337), and Enid Zamudio Moreno a postdoctoral fellowship (167384) provided by CONACyT. 


\section{REFERENCES}

Akpor O.B., Igbinosa O.E. and Igbinosa O.O. (2007). Studies on the effect of petroleum hydrocarbon on the microbial and physico-chemicals characteristics of soil. Afr. J. Biotechnol. 6, 1939-1943.

Alisi C., Musella R., Tasso F., Ubaldi C., Manzo S., Cremisini C. and Sprocati A.R. (2009). Bioremediation of diesel oil in a co-contaminated soil by bioaugmentation with a microbial formula tailored with native strains selected for heavy metals resistance. Sci. Total Environ. 407, 3024-3032. DOI: 10.1016/j.scitotenv.2009.01.011

Ashworth J., Keyes D., Kirk R. and Lessard R. (2001). Standard procedure in the hydrometer method for particle size analysis. Commun. Soil. Sci. Plant. Anal. 32, 633-642. DOI: 10.1081/css-100103897

Atlas R.M. and Bartha R. (1972). Degradation and mineralization of petroleum in sea water: limitation by nitrogen and phosphorous. Biotechnol. Bioeng. 14, 309-318.

Bento F. M., Camargo F. A. O., Okeke B.C. and Frankenberger W.T. (2005). Comparative bioremediation of soils contaminated with diesel oil by natural attenuation, biostimulation and bioaugmentation. Bioresour. Technol. 96, 1049-1055.

DOI: 10.1016/j.biortech.2004.09.008

Bordoloi N.K. and Konwar B.K. (2009). Bacterial biosurfactant in enhancing solubility and metabolism of petroleum hydrocarbons. J. Hazard. Mater. 170, 495505. DOI: $10.1016 /$ j.jhazmat.2009.04.136

Cooper D.G. and Goldenberg B.G. (1987). Surface active agents from two Bacillus species. Appl. Environ. Microbiol. 26, 229-253.

Ellis D.E., Lutz E.J., Odom J.M., Buchanan Jr.R.J. and Bartlett C.L. (2000). Bioaugmentation for accelerated in situ anaerobic bioremediation. Environ. Sci. Technol. 34, 2254-2260. DOI: 10.1021/es990638e

Erdoğan E.E., Şahin F. and Karaca A. (2012). Determination of petroleum-degrading bacteria isolated from crude oil-contaminated soil in Turkey. Afr. J. Biotechnol. 11, 4853-4859.

Escalante-Espinosa E., Gallegos-Martínez M.E., FavelaTorres E. and Gutiérrez-Rojas M. (2005). Improvement of the hydrocarbon phytoremediation rate by Cyperus laxus Lam. inoculated with a microbial consortium in a model system. Chemosphere 59, 405-413. DOI: 10.1016/j.chemosphere.2004.10.034

Fernández Linares L.C., Rojas Avelizapa N.G., Roldán Carrillo T.G., Ramírez Islas M.E., Zegarra Martínez H.G., Uribe Hernández R., Reyes Ávila R.J., Flores Hernández D. and Arce Ortega J.M. (2006). Manual de técnicas de análisis de suelos aplicadas a la remediación de sitios contaminados. Instituto Mexicano del
Petróleo, Secretaría de Medio Ambiente y Recursos Naturales, Instituto Nacional de Ecología, Mexico City, Mexico, 184 pp.

Gentry T.J., Rensing C. and Pepper I. L. (2004). New approaches for bioaugmentation as a remediation technology. Crit. Rev. Env. Sci. Tec. 34, 447-494.

DOI: $10.1080 / 10643380490452362$

Hamdi H., Benzarh S., Manusodzianas L., Aoyama I. and Jedidi N. (2007). Bioaugmentation and biostimulation effects on PAH dissipation and soil ecotoxicity under controlled conditions. Soil Biol. Biochem. 39, 19261935. DOI: $10.1016 /$ j.soilbio.2007.02.008

John R.C., Itah A.Y., Essien J.P. and Ikpe D.I. (2011). Fate of nitrogen-fixing bacteria in crude oil contaminated wetland ultisol. B. Environ. Contam. Tox. 87, 343-353. DOI: $10.1007 / \mathrm{s} 00128-011-0320-1$

Jorgensen K.S., Puustinen J. and Sourtii A.M. (2000). Bioremediation of petroleum hydrocarbon-contaminated soil by composting in biopiles. Environ. Pollut. 107, 245-254. DOI: 10.1016/S0269-7491(99)00144-X

Mancera-López M.E., Esparza-Garcia F., Chávez-Gómez B., Rodríguez-Vázquez R., Saucedo-Castañeda G. and Barrera-Cortés J. (2008). Bioremediation of an aged hydrocarbon-contaminated soil by a combined system of biostimulation-bioaugmentation with filamentous fungi. Int. Biodeter. Biodegr. 61, 151-160.

DOI: $10.1016 /$ j.ibiod.2007.05.012

Medina-Moreno S.A., Jiménez-González A., GutiérrezRojas M. and Lizardi-Jiménez M.A. (2013). Hexadecane aqueous emulsion characterization and uptake by an oil-degrading microbial consortium. Int. Biodeter. Biodegr. 84, 1-7. DOI: 10.1016/j.ibiod.2013.05.018

Merkl N., Kraft R.S. and Infante C. (2005). Phytoremediation in the tropics-influence of heavy crude oil on root morphological characteristics of graminoids. Environ. Pollut. 138, 86-91. DOI: 10.1016/j.envpol.2005.02.023

Molina-Barahona L., Rodríguez-Vázquez R., Hernández-Velasco M., Vega-Jarquin C., Zapata-Pérez O., Mendoza-Cantú A. and Albores A. (2004). Diesel removal from contaminated soils by biostimulation and supplementation with crop residues. App. Soil Ecol. 27, 165-175. DOI: 10.1016/j.apsoil.2004.04.002

Mondello F.J. (1989). Cloning and expression in Escherichia coli of Pseudomonas strain LB400 genes encoding polychlorinated biphenyl degradation. J. Bacteriol. 171, 1725-1752.

Palma-Cruz F.J., Esparza García F., Poggi Varaldo H.M., Rodríguez Vázquez R., Peña Cabriales J.J., Ferrera Cerrato R., Pérez Vargas J. and Calva Calva G. (2004). Changes in the number of plant species in sites from Tabasco, México, chronically polluted with oil. Proceedings. First International Meeting on Environmental Biotechnology and Engineering. Institut de Recherche 
Pour le Developpement-Centro de Investigación y de Estudios Avanzados. Mexico City, Mexico. September 6-8, 2004. CD-ROM.

Palma-Cruz F.J., Pérez Vargas J., Rivera-Casado N.A., Gómez Guzmán O. and Calva-Calva G. (2016). Phytoremediation potential, ecological and phenological changes of native pioneer plants from weathered oil spill impacted-sites. Environ. Sci. Pollut. R. 23, 1635916371. DOI: 10.1007/s11356-016-6675-4

Peng S., Zhou Q., Cai Z. and Zhang Z. (2009). Phytoremediation of petroleum contaminated soils by Mirabilis Jalapa L. in a greenhouse plot experiment. J. Hazard. Mater. 168, 1490-1496.

DOI: 10.1016/j.jhazmat.2009.03.036

Pérez-Vargas J., Anaya Reza O., Chang Solis C.K., Membrillo Venegas I. and Calva Calva G. (2010). Producción de biosurfactantes por bacterias de vida libre fijadoras de nitrógeno crecidas en hidrocarburos. Revista CENIC Ciencias Químicas. 41, 1-9.

Pérez-Vargas J., Poggi-Varaldo H.M., Calva-Calva G., Ríos-Leal E., Rodríguez-Vázquez R., Ferrera-Cerrato R. and Esparza-García F. (2000). Nitrogen-fixing bacteria capable of utilizing kerosene hydrocarbons as a sole carbon source. Water Sci. Technol. 42, 407-410.

Pérez-Vargas J., Palma-Cruz F., Castañeda López C., García Rivero M., Martínez Trujillo A. and CalvaCalva G. (2006). Microbial degradation of aromatic hydrocarbons by atmospheric nitrogen fixing bacteria Isolated from contaminated soil of Tabasco. Proceedings. The Second International Meeting on Environmental Biotechnology and Engineering. Centro de Investigación y de Estudios Avanzados. Mexico City, Mexico. September 26-29, 2006. CD-ROM.

Pérez-Vargas J., Neria González M.I, Membrillo Venegas I.L., Buenrostro Zagal J.F., Vigueras Carmona S.E., Tavera Monrroy S.X. and Calva Calva G. (2011). Microbial remediation of a hydrocarbon-contaminated soil by bioaugmentation technology. Proceedings. International Symposium on Bioremediation and Sustainable Environmental Technologies. Battelle Memorial Institute, Columbus, OH, USA. June 27-30, 2011. CD-ROM

Rennie R. J. (1987). A single medium for the isolation of acetylene-reducing (dinitrogen-fixing bacteria from soils). Can. J. Microbiol. 27, 8-14.
Rivera-Casado N.A., Montes Horcasitasa M.C., Rodríguez Vázquez R., Esparza García F.J., Pérez Vargas J., Ariza Castolo A., Ferrera-Cerrato R., Gómez Guzmán O. and Calva Calva G. (2015). The fatty acid profile analysis of Cyperus laxus used for phytoremediation of soils from aged oil spill-impacted sites revealed that this is a C18:3 plant species. PLoS ONE 10, e0140103. DOI: 10.1371/journal.pone.0140103

Rivera-Cruz M.D., Ferrera-Cerrato R., Sánchez-García P., Volke Haller V., Fernández-Linares L. and RodríguezVázquez R. (2004). Decontamination of soils polluted with crude petroleum using indigenous microorganisms and aleman grass (Echinochloa polystachya). Agrociencia 38, 1-12.

Rojas-Avelizapa N.G., Roldán-Carrillo T., Zegarra-Martínez H., Muñoz-Colunga A.M. and Fernández-Linares L.C. (2003). A field trial for an ex-situ bioremediation of a drilling mud-polluted site. Chemosphere 66, 5951600.

Ruffini Castiglione M., Giorgetti L., Becarelli S., Siracusa G., Lorenzi R. and Di Gregorio S. (2016). Polycyclic aromatic hydrocarbon-contaminated soils: bioaugmentation of autochthonous bacteria and toxicological assessment of the bioremediation process by means of Vicia faba L. Environ. Sci. Pollut. Res. 23, 7930-7941. DOI: 10.1007/s11356-016-6049-y

Semple K.T., Doick K.J., Jones K.C., Burauel P., Craven A. and Harms H. (2004). Defining bioavailability and bioaccessibility of contaminated soil and sediment is complicated. Environ. Sci. Technol. 38, 228A-231A. DOI: $10.1021 / \mathrm{es} 040548 \mathrm{w}$

Tang J., Lu X., Sun Q. and Zhu W. (2012). Aging effect of petroleum hydrocarbons in soil under different attenuation conditions. Agr. Ecosyst. Environ. 149, 109-117. DOI: $10.1016 /$ j.agee.2011.12.020

Tyagi M., da Fonseca M. M. R. y de Carvalho C. C. (2011). Bioaugmentation and biostimulation strategies to improve the effectiveness of bioremediation processes. Biodegradation 22, 231-241. DOI: $10.1007 / \mathrm{s} 10532-010-9394-4$

Vogel T.M. and Walter M.V. (2001). Bioaugmentation. In: Manual of Environmental Microbiology. (C.J. Hurst, R.L. Crawford, J.L. Garland, D.A. Lipson, A.L. Mills, Eds.). American Society for Microbiology Press, Washington D. C., USA, pp. 952-959. 